\title{
Improvement of environmental indicators of coal energy and agricultural production due to the integration and diversification of these industries
}

\author{
Ekaterina Trushkova ${ }^{1, *}$, Elena Omelchenko ${ }^{1}$, and Mikhail Sidelnikov ${ }^{2}$ \\ ${ }^{1}$ Don State Technical University, Gagarin sq., 1, Rostov-on-Don, 344003, Russia \\ ${ }^{2}$ Southern Federal University, st. Bolshaya Sadovaya, 105/42, Rostov-on-Don, 344006, Russia
}

\begin{abstract}
At present, there is extensive experience in the use of sulfuric acid ameliorant for soils with soda type of salinity. The authors found that as a result of using a weak solution of sulfuric acid on soils containing sodium and hydrocarbonates in their salt composition, their agrochemical characteristics are significantly improved. The article presents the results that show that the production of fertilizers and ameliorants from the waste of energy enterprises will increase their environmental safety. The use of sulfur oxides captured from the flue gases of coal-fired energy enterprises as a raw material for the production of sulfuric ameliorant will allow solving a double task: to reduce pollution of the zone of influence of enterprises and improve the condition of lands with soda salinization.
\end{abstract}

\section{Introduction}

National security is implemented by a number of indicators that are closely integrated with each other, for example, such as food security, energy security, environmental security, etc.

The steady trend of recent years is a reduction the strategic stock of food products not only in Russia, but also in most of other countries. According to statistics, as of December 1,2018 , grain reserves in our country amounted to 29.7 million tons, which is $30.2 \%$ less than the $2017 / 2018$ season and $20.4 \%$ less compared to the $2016 / 2017$ season [1-3]. This state of affairs destabilizes the national security of the country.

The «Concept of Enhancing Food Security of the CIS Member States» indicates that the most important criteria for food security in the world are the level of self-sufficiency of the main types of food and the level of their carryover stocks, which should be $15-20 \%$ of annual food consumption in the country.

In order to ensure food security of the Russian Federation, it is necessary to develop comprehensive, scientifically based methods for restoring and maintaining arable land, since the level of food production is directly dependent on the fertility of these soils.

Non-depleting agricultural production technologies in such high volumes do not currently exist. Soil fertility can only be maintained and preserved for a longer period,

\footnotetext{
* Corresponding author: rudenko-centr@mail.ru
} 
which is achieved by introducing various kinds of organic and chemical fertilizers, carrying out recultivations and reclamation of disturbed and unfavorable land, scientifically-based irrigation and sowing of agricultural and other crops.

However, the production of mineral fertilizers in large volumes, ameliorants, mechanized processes of irrigation, sowing, care and harvesting of agricultural products are accompanied by large energy consumption. Yes, and the production of necessary equipment, ensuring the needs of workers in this industry and much more are tied to energy consumption.

The possibility of generating sufficient energy for consumption of the economy and other spheres is the basis of the state's energy security.

According to the approximate estimates given in the «Energy Strategy of Russia for the period until 2030», in the current period the share of different sources in the global energy production are [4-8]: fossil fuels - 80\%; waste and biomass incineration - 10\%; nuclear power plants - 5\%; hydroelectric stations - 5\%; other sources (wind, solar panels, geothermal and marine installations, etc.) $-0.5 \%$.

As can be seen from the above data, the most energy-intensive resource of the planet is fossil fuels, namely, natural gas, oil and coal.

However, the use of these resources for the production of electricity is accompanied by the formation of large amounts of waste.

\section{Materials and method}

To ensure the environmental safety of both individual sectors of the economy and the state as a whole, it is necessary to develop an integrated approach to the above-mentioned branches of the national economy. The possibility of giving the energy industry more environmentally attractive indicators has been repeatedly considered. In this direction, agriculture can become a very promising symbiote of the energy-producing industry.

Considering the chemical potential of the waste of the energy industry, the conclusion suggests itself that it is possible to attract this potential for the needs of agricultural production, which is both environmentally and economically justified [9-11].

For instance, emissions from energy producing enterprises using coal fuels contain a significant amount of sulfur, carbon and nitrogen oxides, which, using traditional capture technologies, can be converted into marketable products demanded in agriculture as fertilizers and ameliorants, which improve soil structure and its salt composition.

For example, technologies have been developed that derive from emissions of sulfuric acid by means of catalytic gas cleaning from $\mathrm{SO}_{2}$ formed during coal combustion. In turn, sulfuric acid is a very successful ameliorative for lands that have soda salinization. At present, soil salinization is a scourge of the main agricultural producing regions, especially when used in crop cultivation of irrigation systems. Thus, in the most irrigated region - the Southern Federal District, about $50 \%$ of saline soils of their total number in the Federation (total $\approx 79 \mathrm{mln}$. Ha) are noted $[5,11,12]$.

In our country and abroad there is a wide experience of using sulfuric acid improver for soils having soda type salinity. Soda salinization during irrigation dramatically reduces the productivity of agricultural crops, causes deep negative transformations of the entire soil mass, both organic and mineral.

\section{Results and discussion}

As a result of the use of a weak solution of sulfuric acid (0.8-1.0\%) on soils having sodium and bicarbonate in the salt composition, their agrochemical characteristics are significantly 
improved. The results are shown in tables $1-4$.

To maintain agricultural biomass production at an appropriate level, and, above all, in crop production, it is necessary to constantly saturate the soil with essential nutrients. The main sources of nutrients and trace elements are currently mineral fertilizers. Of the abovementioned components of the exhaust gases of energy enterprises, it is possible to obtain various types of macro-fertilizers, such as ammonium nitrate $-\mathrm{NH}_{4} \mathrm{NO}_{3}$ and ammonium sulfate $-\left(\mathrm{NH}_{4}\right)_{2} \mathrm{SO}_{4}$.

This technology was developed by VTI specialists for the simultaneous purification of flue gases from $\mathrm{NOx}$ and $\mathrm{SO} 2$ to produce a mixture of $\mathrm{NH} 4 \mathrm{NO} 3$ and (NH4)2SO4 fertilizers and was tested on a pilot plant of the Moldavskaya GRES [13, 14]. Its essence lies in the fact that a strong oxidant is introduced into the exhaust gases - ozone, which oxidizes the lower low-reaction oxides of sulfur and nitrogen (SO2 and NO) to higher (SO3 and N2O5). In turn, higher oxides easily dissolve in water and aqueous solutions, which makes it possible to obtain in the process of gas purification acid solutions, which are then neutralized by ammonia.

Table 1. The salt composition of the extract on the monolith to acidification (Experimental demonstration farm «Elkinsky» Bagaevsky district, Rostov region).

\begin{tabular}{|c|c|c|c|c|c|c|c|}
\hline \multirow{2}{*}{ Depth, $\mathrm{sm}$} & \multicolumn{3}{|c|}{ Cations, $\mathrm{m} \cdot$ eq. } & \multicolumn{4}{|c|}{ Anions, $\mathrm{m} \cdot$ eq. } \\
\cline { 2 - 8 } & $\mathrm{Ca}^{2+}$ & $\mathrm{Mg}^{2+}$ & $\mathrm{Na}^{+}$ & $\mathrm{CO}_{3}^{2-}$ & $\mathrm{HCO}_{3}^{-}$ & $\mathrm{SO}_{4}^{2-}$ & $\mathrm{Cl}^{-}$ \\
\hline $0-20$ & $\frac{1,60}{0,064}$ & $\frac{0,10}{0,001}$ & $\frac{7,30}{0,168}$ & $\frac{3,51}{0,105}$ & $\frac{1,63}{0,099}$ & $\frac{0,99}{0,049}$ & $\frac{2,87}{0,101}$ \\
\hline $20-40$ & $\frac{2,06}{0,082}$ & $\frac{0,33}{0,004}$ & $\frac{7,92}{0,182}$ & $\frac{2,11}{0,063}$ & $\frac{3,99}{0,243}$ & $\frac{2,13}{0,104}$ & $\frac{2,08}{0,073}$ \\
\hline $40-60$ & $\frac{2,43}{0,097}$ & $\frac{0,48}{0,006}$ & $\frac{8,09}{0,186}$ & $\frac{0,90}{0,028}$ & $\frac{4,42}{0,270}$ & $\frac{3,21}{0,157}$ & $\frac{2,43}{0,085}$ \\
\hline $60-80$ & $\frac{2,80}{0,112}$ & $\frac{0,50}{0,006}$ & $\frac{8,80}{0,202}$ & $\frac{0,48}{0,014}$ & $\frac{5,80}{0,354}$ & $\frac{2,50}{0,123}$ & $\frac{3,32}{0,116}$ \\
\hline $80-100$ & $\frac{2,00}{0,080}$ & $\frac{0,41}{0,005}$ & $\frac{10,00}{0,230}$ & - & $\frac{7,80}{0,475}$ & $\frac{2,00}{0,098}$ & $\frac{2,61}{0,091}$ \\
\hline
\end{tabular}

Nitrogen - one of the main elements necessary for plants. It enters into all simple and complex proteins, which are the main component of the protoplasm of plant cells.

However, nitrogen is most accessible to plants in the form of mineral compounds and, only in an insignificant proportion, in the form of amides dissolved in water and the simplest amino acids. Meanwhile, the bulk of nitrogen in the soil, which is in various organic compounds, is not available to plants. Only a small amount of nitrogen (about $1 \%$ of the total) is found in the plant-assimilated mineral compounds.

With this specific bioavailability of nitrogen, a progressive increase in crop yields is possible only with a combination of legumes that provide biological synthesis of nitrogen, along with symbionts (nodule bacteria) with full use of manure and extensive use of mineral nitrogen fertilizers. The results are shown in table 5.

Comparing the required nutrients (without taking into account the synergy of effects), we can conclude that nitrogen fertilizer has a priority effect on the harvest, since the yield increase from nitrogen is half the total effect of the total mineral fertilizer.

The yield of the main crop - wheat in the Russian Federation over the past four years (2015-2018) ranged from 21 to 28 centners per hectare, which required a steady average of $70 \mathrm{~kg}$ of nitrogen per hectare of arable land. The results are shown in table 5 . The amount 
of crops under grain crops is about 40 million hectares, which will require the introduction of mineral fertilizers to about 2.8 million tons of nitrogen only $[14,15]$, not to mention the other elements necessary for restoring soil fertility.

Table 2. Salt composition of the extract on the monolith after the introduction of ameliorant (Experimental demonstration farm «Elkinsky» Bagaevsky district, Rostov region).

\begin{tabular}{|c|c|c|c|c|c|c|c|}
\hline \multirow{2}{*}{ Depth, sm } & \multicolumn{3}{|c|}{ Cations, $\mathrm{m} \cdot$ eq. } & \multicolumn{4}{|c|}{ Anions, $\mathrm{m} \cdot$ eq. } \\
\cline { 2 - 8 } & $\mathrm{Ca}^{2+}$ & $\mathrm{Mg}^{2+}$ & $\mathrm{Na}^{+}$ & $\mathrm{CO}^{2-}$ & $\mathrm{HCO}_{3}{ }^{2-}$ & $\mathrm{SO}_{4}{ }^{2-}$ & $\mathrm{Cl}^{-}$ \\
\hline $0-20$ & $\frac{3,00}{0,120}$ & $\frac{1,12}{0,014}$ & $\frac{3,01}{0,069}$ & - & $\frac{1,07}{0,065}$ & $\frac{5,91}{0,290}$ & $\frac{0,15}{0,005}$ \\
\hline $20-40$ & $\frac{2,90}{0,116}$ & $\frac{2,30}{0,028}$ & $\frac{4,02}{0,092}$ & - & $\frac{1,87}{0,114}$ & $\frac{6,30}{0,309}$ & $\frac{1,05}{0,037}$ \\
\hline $40-60$ & $\frac{6,01}{0,240}$ & $\frac{2,03}{0,025}$ & $\frac{4,05}{0,093}$ & $\frac{0,23}{0,007}$ & $\frac{2,88}{0,176}$ & $\frac{6,56}{0,321}$ & $\frac{2,42}{0,085}$ \\
\hline $60-80$ & $\frac{5,12}{4,205}$ & $\frac{4,50}{0,055}$ & $\frac{3,06}{0,070}$ & $\frac{0,25}{0,008}$ & $\frac{3,01}{0,184}$ & $\frac{5,81}{0,285}$ & $\frac{3,61}{0,126}$ \\
\hline $80-100$ & $\frac{5,01}{0,200}$ & $\frac{2,00}{0,024}$ & $\frac{4,47}{0,102}$ & $\frac{0,25}{0,008}$ & $\frac{3,61}{0,220}$ & $\frac{4,62}{0,226}$ & $\frac{3,00}{0,105}$ \\
\hline
\end{tabular}

Table 3. Salt composition of the extract on the monolith after acidification and washing (Experimental demonstration farm «Elkinsky» Bagaevsky district, Rostov region).

\begin{tabular}{|c|c|c|c|c|c|c|c|}
\hline \multirow{2}{*}{ Depth, sm } & \multicolumn{3}{|c|}{ Cations, $\mathrm{m} \cdot$ eq. } & \multicolumn{5}{|c|}{ Anions, $\mathrm{m} \cdot$ eq. } \\
\cline { 2 - 8 } & $\mathrm{Ca}^{2+}$ & $\mathrm{Mg}^{2+}$ & $\mathrm{Na}^{+}$ & $\mathrm{CO}_{3}{ }^{2-}$ & $\mathrm{HCO}_{3}{ }^{-}$ & $\mathrm{SO}_{4}{ }^{2-}$ & $\mathrm{Cl}^{-}$ \\
\hline $0-20$ & $\frac{1,02}{0,041}$ & $\frac{0,92}{0,011}$ & $\frac{2,20}{0,051}$ & - & $\frac{0,75}{0,046}$ & $\frac{3,15}{0,154}$ & $\frac{0,24}{0,008}$ \\
\hline $20-40$ & $\frac{2,00}{0,080}$ & $\frac{1,72}{0,021}$ & $\frac{4,52}{0,104}$ & $\frac{0,20}{0,006}$ & $\frac{1,30}{0,079}$ & $\frac{5,82}{0,285}$ & $\frac{0,92}{0,032}$ \\
\hline $40-60$ & $\frac{3,00}{0,120}$ & $\frac{2,48}{0,030}$ & $\frac{4,60}{0,106}$ & $\frac{0,20}{0,006}$ & $\frac{2,53}{0,154}$ & $\frac{6,22}{0,305}$ & $\frac{1,13}{0,040}$ \\
\hline $60-80$ & $\frac{3,01}{0,120}$ & $\frac{2,50}{0,030}$ & $\frac{4,00}{0,092}$ & $\frac{0,10}{0,003}$ & $\frac{3,08}{0,188}$ & $\frac{5,46}{0,267}$ & $\frac{0,87}{0,031}$ \\
\hline $80-100$ & $\frac{3,00}{0,120}$ & $\frac{2,50}{0,030}$ & $\frac{4,21}{0,097}$ & $\frac{0,20}{0,006}$ & $\frac{3,05}{0,186}$ & $\frac{4,61}{0,226}$ & $\frac{1,85}{0,065}$ \\
\hline
\end{tabular}

Table 4. Change of agrochemical properties of the soil (Experimental demonstration farm «Elkinsky» Bagaevsky district, Rostov region).

\begin{tabular}{|c|c|c|c|c|c|c|}
\hline \multirow{2}{*}{ Experience options } & \multicolumn{6}{|c|}{ Nutrient content of soil horizons } \\
\cline { 2 - 7 } & \multicolumn{2}{|c|}{$\begin{array}{c}\text { Nitrogen, } \mathrm{mEq} / 100 \\
\mathrm{~g}\end{array}$} & \multicolumn{2}{|c|}{$\begin{array}{c}\text { Phosphorus, mEq / 100 } \\
\mathrm{g}\end{array}$} & \multicolumn{2}{|c|}{ Potassium, mEq / 100 g } \\
\cline { 2 - 7 } & $0-30$ & $30-60$ & $0-30$ & $30-60$ & $0-30$ & $30-60$ \\
\hline $\begin{array}{c}\text { Before land } \\
\text { reclamation }\end{array}$ & 0,080 & 0,061 & 4,9 & 8,7 & 16,3 & 18,6 \\
\hline After land reclamation & 0,083 & 0,064 & 5,8 & 10,6 & 13,6 & 17,5 \\
\hline
\end{tabular}


Table 5. Approximate removal of basic nutrients with the yield of some crops in $\mathrm{kg} / \mathrm{ha}$ of active substance.

\begin{tabular}{|c|c|c|c|c|}
\hline \multirow{2}{*}{ Crops } & The harvest of the main & \multicolumn{3}{|c|}{ Delivered with a crop, $\mathrm{kg} / \mathrm{ha}}$. \\
\cline { 3 - 5 } & products $\mathrm{t} / \mathrm{ha}$. & $\mathrm{N}$ & $\mathrm{P}_{2} \mathrm{O}_{5}$ & $\mathrm{~K}_{2} \mathrm{O}$ \\
\hline Cereals & $30-35$ & $90-110$ & $30-40$ & $60-90$ \\
\hline Winter rye & $25-30$ & $85-90$ & $36-40$ & 78 \\
\hline Winter wheat & 30 & 75 & 52 & 82 \\
\hline Spring wheat & 30 & 60 & 24 & 84 \\
\hline Legumes & $25-30$ & $100-150$ & $35-45$ & $50-80$ \\
\hline Potatoes & $200-250$ & $120-200$ & $40-60$ & $180-300$ \\
\hline Barley & 30 & 80 & 33 & 63 \\
\hline Sugar beet & $400-500$ & $180-250$ & $55-80$ & $250-400$ \\
\hline Corn (h. mass) & $500-700$ & $150-180$ & $50-60$ & $180-250$ \\
\hline Cabbage & $500-700$ & $160-230$ & $65-90$ & $220-320$ \\
\hline Cotton & $30-40$ & $160-220$ & $50-70$ & $180-240$ \\
\hline Linen & 7 & 78 & 30 & 69 \\
\hline Cons & & & & \\
\hline
\end{tabular}

Considering that the average selling price for mineral fertilizers in the country is significantly lower than export, most of the fertilizers produced in Russia go to foreign markets - about $70 \%$.

Russian agricultural producers often do not have the necessary funds to purchase mineral fertilizers in full.

In turn, the prices of agricultural products are not so high that its producers can receive large profits. The results are shown in table 6 .

Table 6. Prices for main grains (according to the materials of the newsletter dated December 7, 2018 and Federal State Budgetary Institution «Special center in the agro-industrial complex»).

\begin{tabular}{|c|c|c|c|c|c|c|}
\hline Price (RUB / t, VAT included) & $\begin{array}{l}\text { wheat } \\
\text { grade } 3\end{array}$ & $\begin{array}{l}\text { wheat } \\
\text { grade } 4\end{array}$ & $\begin{array}{l}\text { wheat } \\
\text { grade } 5\end{array}$ & rye prod. & $\begin{array}{l}\text { barley } \\
\text { fodder. }\end{array}$ & corn for grain \\
\hline Central Federal District & $\begin{array}{l}9500- \\
10500\end{array}$ & $\begin{array}{l}9200- \\
10500\end{array}$ & $\begin{array}{l}9000- \\
10300\end{array}$ & $7000-8300$ & $7300-8400$ & $8600-9000$ \\
\hline $\begin{array}{c}\text { Southern Federal District+ North } \\
\text { Caucasian Federal District }\end{array}$ & $\begin{array}{l}10500- \\
11500\end{array}$ & $\begin{array}{c}10450- \\
10700\end{array}$ & $\begin{array}{c}10000- \\
10200\end{array}$ & - & $8600-9200$ & $8700-9500$ \\
\hline Volga Federal District & $\begin{array}{l}9500- \\
10500\end{array}$ & $\begin{array}{l}9200- \\
10200\end{array}$ & $\begin{array}{l}8400- \\
9600\end{array}$ & $6200-7500$ & $7300-8000$ & $8200-8900$ \\
\hline Ural Federal District & $\begin{array}{l}8500- \\
9600\end{array}$ & $\begin{array}{l}8500- \\
9300\end{array}$ & $\begin{array}{l}8200- \\
9200\end{array}$ & $6000-7000$ & $7000-8500$ & - \\
\hline Siberian Federal District & $\begin{array}{l}8500- \\
10000\end{array}$ & $\begin{array}{l}8000- \\
9700\end{array}$ & $\begin{array}{c}8000- \\
9300\end{array}$ & $6500-7000$ & $6700-8400$ & - \\
\hline
\end{tabular}

Considering that in 2018 , due to weather conditions, a smaller crop was obtained against previous years, and most of the suppliers' deals were futures, prices for main grains 
increased almost twice as compared to the previous year. However, even higher prices for agricultural food do not allow independent profitable reproduction by agricultural producers of their goods without state subsidies.

\section{Conclusion}

In connection with the above facts we can draw the following conclusions.

1.There is a tendency to loss of fertility by soils due to their salinization and removal of substances with the crop in the most agricultural-producing subjects of the Russian Federation

2. Mineral acids, for example, sulfuric acid are a very effective ameliorative for soil salinization, the most toxic of all types of salinization.

3. Use as a raw material for the production of sulfuric acid ameliorates sulfur oxides trapped from the flue gases of energy enterprises operating on coal, will solve a dual problem: to reduce pollution of the zone of influence of enterprises and to improve the condition of the land with soda salinization.

4. Given the active use of arable land, which is accompanied by the removal of nutrients from the crop, it is necessary to constantly maintain the fertility of these lands by introducing various types of fertilizers.

5. Taking into account the difference between the selling price for mineral fertilizers inside the country and on the world market, as well as the financial condition of the agricultural sector, the offer for sale of effective fertilizers produced on the basis of waste may be a promising alternative to traditionally obtained.

\section{References}

1. Trushkova E., Omelchenko E. Determination of Factors of Professional Health Risk of Engineering Workers. In: Popovic Z., Manakov A., Breskich V. (eds) VIII International Scientific Siberian Transport Forum. TransSiberia 2019. Advances in Intelligent Systems and Computing, 1116 Springer, Cham. (2020)https://doi.org/10.1007/978-3-030-37919-3_79

2. Cao, B.-S., Zou, C.-X., Gao, J.-X., He, P. Review on methodology and application of ecological security assessment, Journal of Ecology and Rural Environment 35 (8), 1673-4831 (2019)08-0953-11, 953-963 (2019)

3. Burkov, V., Titarenko, B. Economic mechanisms for environmental risk management, E3S Web of Conferences 91, 08009 (2019)

4. Matveeva A.A., Ladonina E. Yu., Popova O. Yu., Some approaches to management and provision of industrial and environmental safety at regional enterprises, 1st International Scientific Practical Conference on Breakthrough Technologies and Communications in Industry, BTCI 2018; Volgograd State University, Volgograd; Russian Federation IOP Conference Series: Materials Science and Engineering 483, 1, 20 (2019)

5. Omelchenko E.V., Trushkova E.A., Sidelnikov M.V., Pushenko S.L., Staseva E.V.: Algorithm research exposure dust emissions enterprises of building production on the environment. IOP Conf. Ser.: Earth Environ. Sci. 50, 012018 (2017). DOI: $\underline{10.1088 / 1755-1315 / 50 / 1 / 012018}$

6. Sorgog, K., Kamo, M., Quantifying the precision of ecological risk: Conventional assessment factor method vs. species sensitivity distribution method, Ecotoxicology and Environmental Safety 183 (2019) 
7. Griffin R.L., Uncertain about uncertainty in pest risk analysis, Acta Horticulturae 1105, 315-320 (2015)

8. Holt J., Leach A.W., Linguistic variables as fuzzy sets to model uncertainty in the combined efficacy of multiple phytosanitary measures in pest risk analysis, Ecological Modelling 406, 73-79 (2019)

9. Omelchenko E.V., Trushkova E.A., Pushenko S.L., Firsov V.A., Sitnik S.V.: Technique of an Assessment of Industrial Safety of Paint and Varnish Productions. IOP Conference Series Earth and Environmental Science 66(1):012031(2017).DOI: 10.1088/1755-1315/66/1/012031

10. Glen N., Korol O., André L., Robert F., Tom G., Extracting pest risk information from risk assessment documents, Proceedings of the ACM/IEEE Joint Conference on Digital Libraries (2019)

11. Jeger M., Bragard C., Caffier D., Candresse T., Chatzivassiliou E., Dehnen-Schmutz K., Grégoire J.-C., Jaques M.J.A., MacLeod A., Navajas N.M., Niere B., Parnell S., Potting R., Rafoss T., Rossi V., Urek G., Van Bruggen, A., Van Der Werf W., West J., Winter S., Hart A., Schans J., Schrader G., Suffert M., Kertész V., Kozelska S., Mannino, M.R., Mosbach-Schulz, O., Pautasso, M., Stancanelli, G., Tramontini, S., Vos, S., Gilioli, G., EFSA Panelon Plant Health (PLH) Guidance on quantitative pest risk assessment, EFSA Journal 16 (8) (2018)

12. Baptistucci C.B., Pech G., Carvalho M.M., Experts' engagement in risk analysis: A model merging analytic hierarchy, Journal of Modern Project Management 6 (1), 6-17 (2018)

13. Soukar L., Natural resources endowment and WTO, Journal of Economic Integration 34 (3), 546-589 (2019)

14. Pysarenko P.V., Samojlik M.S., Plaksiienko I.L., Kolesnikova L.A., Conceptual framework for ensuring resource and environmental safety in the region, Theoretical and Applied Ecology (2), 137-142 (2019)

15. Likhachev S., Borenstein A., Raksha N., Larina E.m Ensuring environmental safety from the perspective of the protection of the national interests of the state, International Multidisciplinary Scientific Geo Conference Surveying Geology and Mining Ecology Management, SGEM 19 (5.4), 459-464 (2019) 